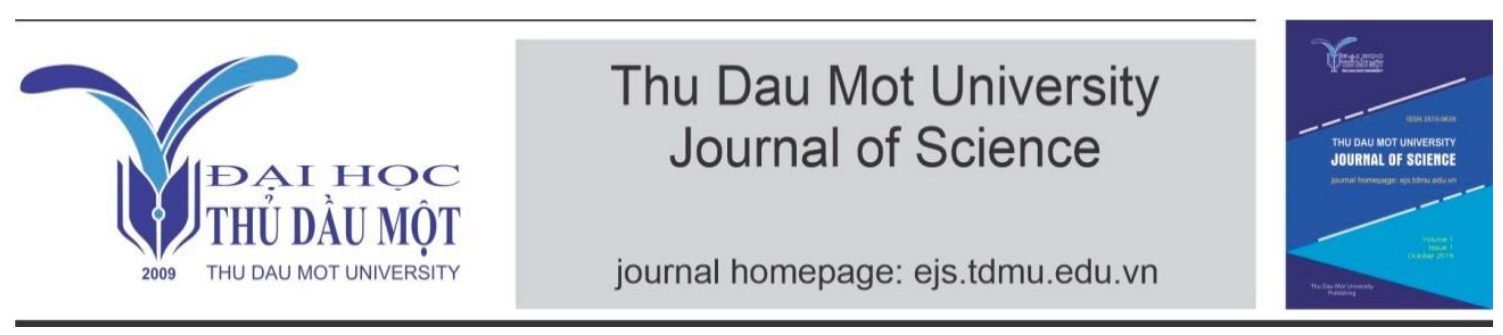

\title{
The Advantages and Disadvantages on Teaching and Learning English in Online Setting
}

by Huỳnh Bảo Ngọ (Thu Dau Mot University)

Article Info: Received 10 April. 2021, Accepted 2 June 2021, Available online 15 June 2021

Corresponding author: ngochb@tdmu.edu.vn

https://doi.org/10.37550/tdmu.EJS/2021.02.206

\begin{abstract}
This paper explores the pros and cons of using an online setting for teaching and learning English comparing with an in-class setting. The online setting is undergoing a fast transformation and becomes a widely promoted platform due to the COVID-19 pandemic. By reviewing different studies on online teaching, this paper aims to understand the online setting better. This information would be helpful to Vietnam, where the online class has a medium used and short history comparing with other developed and developing countries, so online classes in Vietnam may need adjustment and consideration based on different cultures and learner's experiences. This paper also gives some suggestions for online learning design for English languages to increase learning effectiveness.
\end{abstract}

Keywords: online education, distance learning, online instruction, English languages

\section{Introduction}

English is one of the most globalized and diverse foreign language learning worldwide, especially in East Asia (Byram, 2008). According to Ling and Brown's research, English had been used for communication and learning in more than 75 countries and reached half a billion people who spoke English as a foreign language in 2015. In China, the English language has been studied for more than 100 years. The first English school was established during the late Qing Dynasty (1861-1911). English was introduced to Korea in 1882 based on the evidence of the signed foreign treaty between the United States and Korea (Lam and Chow, 2004; Baik, 1992). Compared to those 
two countries, English may have a shorter history in Vietnam since it has been taught as the main subject for students from first grade at primary school since the 1990s. It has become a compulsory part of high-schools and college matriculation examinations (Nguyen, 2005).

In Vietnam, more than $90 \%$ of students in most cities and provinces choose to study English over other languages such as Russian, French, Chinese, German, and Japanese (Dan Tri News, 2016; Tien Phong News, 2016). There are many reasons why this language becomes more popular and gets more attention from governments, organizations, and individuals. With an increasingly active in globalization and international affairs, the Vietnamese government believes that learning excellent and efficient English is vital for achieving national economic and international marketplace success as a long-term strategy. For individuals, English is a prerequisite for finding a desirable and high salary or getting a job promotion since most well-paid foreign enterprises and joint ventures are significantly dependent on good English communication and performance at work. Besides that, studying English to get high scores in different kinds of tests such as the International English Language Testing System (IELTS), the Graduate Record Examinations (GRE), or the General Management Admission Test (GMAT) is essential for getting a ticket to study abroad. As a result, there is a huge demand for learning English in Vietnam that created mushroomed private training centers besides providing classes by schools or universities.

Traditionally, teaching in-class settings is in which teachers and students have to face counterparts face-to. In contrast, online learning is one of the increasingly popular methods welcomed by universities and institutions to meet students' demands of learning English (Rumble \& Latchem, 2004). Teaching English in an online setting has many benefits that attracted more attention from students who seek an opportunity to increase their English language proficiency despite long distance and hectic schedules (Bates, 2005; Harnett et al., 2011). By choosing to study online courses, both teachers and students can keep their regular working schedule while saving time and money for traveling to physical studying venues (England, 2012).

However, Language subject as English is different from other subjects that students study at school since it involves both personal and social aspects (Dörnyei, 1996). According to Dörnyei, it is not only a personal matter to study English languages effectively but also affected by many environmental and social factors such as the status or power of the languages, which can also affect the person's motivation to learn them (1996).

Motivation is an essential factor as a resource of energy for us to keep learning since it 
can influence what we choose to learn, how we learn, and when we learn (Paris \& Turner, 1994; Schunk \& Usher, 2012). According to Kim and Frick's study, learning English online is challenging that both students and teachers will face (2011). Based on a survey with 368 adult learners who participated in e-learning courses, Kim and Frick found that most learners (94.2\%) chose online training because it is flexible and fits better to their schedule. However, teachers need to avoid overwhelming students by making sure the content of the online course is relevant to students' lives and the difficult level of the course matches with student ability because it has a strong effect on students' learning motivation. So the online course will not be overwhelming (Kim \& Frick, 2011). Besides that, technical difficulties are another obstacle in online learning and teaching (Webster \& Hackey, 1997). Based on the survey of more than 200 employees who work for different organizations from different countries, more than half of participants $(77 \%)$ had interruptions that made them unable to complete the course in one attempt (Baldwin-Evans, 2004).

Furthermore, emotions play an essential role in the learning process since they can increase or decrease the motivation of learners (Dirkx, 2001; Yorks \& Kasl, 2002). Zembylas conducted a study analyzing the emotional aspect of adult learners who had no experience with online learning toward distance education (2008). Besides feeling enthusiasm and excitement from the flexibility and fulfilling the course requirement, the authors found that students had many negative emotions about anxiety toward a new type of learning, isolation, and stress about balancing their roles and responsibilities (Zembylas, 2008).

According to Schieb and Karabenick (2011), there are many courses related factors in the success of student's learning in online learning specifically that both teachers and students need to consider, such as content and design, and timing (Egbert \& Thomas, 2001) as in offline teaching, technical support and participants' motivations and attitudes are other factors that play an essential role in the outcome of learning (Sabatini et al., 2000; Cimer, Cakir\&Cimer, 2010)

This paper researches different views points of institutions, lecturers, and students on online classes. Since there are still many challenges and difficulties in applying entirely computer-based for language learning, this paper will overview and compare the pros and cons of learning and teaching English in an online setting. Hence, students and teachers have better knowledge for their decision-making in learning and designing the online course.

\section{Findings and discussion}

Online education is significantly growing in recent years with the help of technology. In 
the United States, the number of students studying online classes was increased two times within five years from 2002 to 2007 with about 3.94 million (Alien \& Seaman, 2008). Alien and Seaman received responses from 2,577 schools out of 4,491 institutions that are still active, and degree-granting for higher education in the USA participated in the survey about online learning. Based on the survey of Alien and Seaman from 2003 to 2007 and data collection of Babson Survey Research Group, there is an increase in the enrollment of online course due to the rise in fuel costs and rising unemployment. Furthermore, many institutions believe that online education is critical and plays an essential role in their long-term strategy (Alien \& Seaman, 2008). In their study, the percentage of US institutions agreed to the vital role of online education was $56.0 \%$ (2004), 58.4\% (2005), 59.1\% ( 2007), and 58\% in schools in 2007.

\subsection{The Advantages of Online Class}

\subsubsection{Variety of Supporting Tools}

Online education is significantly growing in recent years with the help of technology. Instead of focusing on delivering knowledge only as an instructor, an online class is also seeking to build a learning environment and online communities to support students' engagement in a course (Adams, 2007; Bober \& Dennen, 2001). In the past, instructors may have had a hard time designing an online course that stimulates student interaction with limited time and knowledge (Revere et al., 2011). However, various online tools support online teaching that instructors can easily access and use for their courses these days. Discussion boards and chat sessions are great tools to provide an area where students can ask questions, give advice, and share resources for other classmates, helping students connect with their classmates better (Moule,2006). Besides, many free online applications such as Twitter feeds also improve communication within an online class. According to Wetzel's research, Twitter provides a well-rounded environment for data collection, communication with classmates, instructors and other experts, and update news (2009). Similarly, the Google application is also free to use and helpful for instructors and students to organize lessons and arrange their study time (Revere et al., 2011).

\subsubsection{Safe Learning Environment during the pandemic}

In 2019, the COVID-19 outbreak was started in December and declared the Public Health Emergency of International Concern by the World Health Organization in January 2020. Due to safety issues, many governments from different countries have to implement lockdowns, facility closures, travel bans, and especially school closures (Dong et al., 2020). According to UNESCO, more than 95\% of the total students worldwide who study preschool, schools, and universities affect and have to stop faceto-face teaching (2020). Under such crisis circumstances, educational institutions and 
teachers have to replace in-class settings like before using internet platforms for online learning. This change is providing learning opportunities while making sure everyone safe from the COVID-19.

\subsubsection{Atmosphere}

According to qualitative research by Wang and Woo in 2007, the atmosphere is one of the main factors that has higher positive points in an online discussion comparing to an in-class setting. Online discussion has nine positive feedback and two negative feedback, while there are 0 positive feedback and ten negative feedbacks toward faceto-face discussion (Wang \& Woo, 2007). According to their study, even though students could feel more natural by talking and discussing face-to-face with their classmates, the online setting provides a better environment for class discussion, especially for introverted characters (2007). According to Warschauer, people feel more comfortable and relaxed with online discussion because it provides them equal opportunities to raise their voice during the class discussion (1995). In his study in 1995, Warschauer researched the English language performance of a small group of international students who studied English as Second Languages (ESL) class between traditional face-to-face and online. The data showed that students had a higher positive response score toward electronic discussion than face-to-face discussion in terms of feeling freely to express their opinions (3.93 for online and 3.27 for face-to-face discussion). Students also had a better attitude toward an online course for discussion sections rather than face-to-face communication. Based on the scale of 5 is maximum, students felt less stress with 1.87/5.0 for online discussion rather than face-to-face discussion with 2.80/5.0. Furthermore, students could express their feeling more freely in online discussion with 3.87/5.0, which is higher than face-to-face with 3.53, and be more creative in online discussion (3.6/5.0) than only 3.27 in a face-to-face manner (Warschauer, 1995).

\subsubsection{Increasing the flow of learning the English language}

According to the research of Csikszentmihalyi (1975) and Egbert (2003), flow is defined by intense concentration and involvement of learners on a task that helps them improve their performance at high levels. In an online class, students have to deal with tasks and assignments step-by-step to fully involve with the task and understand the learning context better. To examine the flow of English learning in an online class, Liu and Song research the learning experiences of 258 high school students from the age of 14 to 15 years in doing online tasks. According to Liu and Song's research, most students agreed that learning English online with more activities provides pleasant experiences and helps them concentrate and involve better on a task (2021). Class activities are key elements to draw attention and stimulate students' interest in studying (Ro et al., 2018). 
Based on Dellos's study, game-based learning plays a vital role in engagement, increasing motivation and creativity among learners (2015). Dellos'research confirmed that these activities significantly increase the participant's learning process in an active way. Learners can also feel relaxed and confident in class, which triggers interaction and communication skills in language studies (Dellos, 2015).

To examine how the English learning process can improve by playing computer games from students' perspective, Turgut and İrgin had qualitative research on groups of primary and secondary students from 10 to 14 years old in Turkey who played computer games in cyber cafes. Through their observations and interviews, online games help to enhance and improve English learning in students, especially vocabulary.

Similar to Turgut and İrgin's study, Aghlara and Tamjid researched the difference between computer games and traditional in-class study methods on learning and cognitive process of 40 young girls from six to seven-year-old who did not know the English language before the study (2011). The girls were divided into experiment groups in which 20 students used the digital game to learn their lesson and the control group of 20 students without using the digital game in their learning process. Based on the research, children in the experiment group had a higher score on the vocabulary test than the control group, with the mean at 7.8 and 6.6, respectively. These data were significantly different with $\mathrm{p}=0.042$ in the independent t-test analysis (Aghlara \& Tamjid, 2011). Therefore, online class with various game-based assignments has a positive impact on the students' language learning process (Hong et al. 2017).

\subsection{The Disadvantages of Online Class}

\subsubsection{Responses}

The response is another factor that shows a clear difference between online and in-class study that teachers should consider when teaching online. Wang and Woo conducted a study of 24 students taking both online and face-to-face sections for their feedback to understand the different between those two settings better. Based on Wang and Woo's research (2017), the figure of positive and negative feedbacks on responses in a face-toface setting is 13 positive points and 0 negative points, while the figure of positive and negative feedbacks on responses in an online setting is 0 positive point and two negative points. The face-to-face setting has higher positive feedback from students than online discussion since participants can get feedback immediately from other people (Wang \& Woo, 2017). Instructors and learners in the study agreed they spent less time identifying and solving miscommunication and misinterpretation during in-class settings. In contrast, it would take a longer time to do so for the online class. As a result, online classes will require more time to spend on each activity, so assignments requiring a fast response will not be suitable for online classes. 


\subsubsection{Efficiency}

Another drawback of online teaching besides responses is efficiency. Based on Wang and Woo's study, the figure on efficiency in a face-to-face setting is 6 points for positive feedback and 0 points for negative feedback. On the opposite, online sessions have 0 positive points and six negative points of inefficiency (Wang \& Woo, 2017). Similarly, Hiltz and her team had experiments to understand better communication efficiency from the outcome of the communication process between online and face-to-face conferences (1986). A group of participants in online conferences had a slower response from her studies because of typing time, which led to less communication than groups having face-to-face conferences. Hiltz's team research also found less agreement between participants in online conferences than face-to-face conferences. According to their data, four out of eight face-to-face groups reached an agreement, but there was no agreement of groups for online conferences (Hiltz, Johnson \& Turoff, 1986). Online settings will make students take longer time to respond because of other environmental factors such as time for thinking ideas, typing in words, and sending their responses on the discussion board (Hiltz, Johnson \& Turoff, 1986). Besides that, lacking computer skills may also affect how fast students can deliver their answers to make students feel stressed. These kinds of issues can be limited in face-to-face discussion. Teachers need to consider face-to-face conversation over online debate if they want to assign an assignment with a short time frame (Wang \& Woo, 2017).

\subsubsection{Interactivity}

Interactivity is also an essential element that teachers have to consider its restriction while teaching an online class. According to Card and Horton's study, students in the online course had limited interaction than in class. Students in online discussions tend to have one-way communication. Students will respond to a debate topic and rarely receive any comment or feedback from other students in the same group (Card \& Horton, 2000). Based on their study, students in face-to-face discussion will engage in the conversation by asking questions, responding to questions, giving opinions, or even challenging each other (2000). However, Hiltz had a different view of the interactive perception in an online setting than in face-to-face class (1986). Based on several studies of Hiltz, Hiltz believed that online courses have a better study platform for students to do activities by providing easier access between students and professors and increasing their participation rate in class (1988). Therefore, interactivity can be considered a good or weakness of online classes depending on participants' personalities and interests.

\subsubsection{Communication}

Communication is another disadvantage in an online class setting that cannot avoid 
compared to a face-to-face environment. In the research of Johnson, he asked 56 students with the age range from 17 to 34 years to provide their feedback on using different ways of communication, namely cell phone, telephone, email, face-to-face, message, etc. (2000). Students preferred to use face-to-face communication with 20 good feedbacks more than online format with only 0 good feedback from the study. The reason is that they can connect and interact with their classmates in different ways, such as facial expression, tone of voice, gesture, which can help them express their thoughts clearer (Johnson et al., 2000). On the opposite, students can only communicate with each other through typing texts in the online class. Furthermore, they have to spend extra time and effort to pay attention to grammar and vocabulary to ensure that their ideas can deliver clearly to other audiences (Wang \& Woo, 2017).

\section{Conclusion}

This paper has summarized some benefits and issues of adapting the online format in learning and teaching the English language. Although most analytical studies are based on a small size of samples, so it may not be generalizable for a more significant population as a whole, they still provide a better understanding of this new way of learning and teaching with both positive and negative sides of the online format.

The paper also helps to understand the reasons for increasing the demand for online platforms for education, especially in the COVID-19 pandemic. Online teaching and learning are succeeded in introducing and accepting by people. It will continue to use and apply more and more soon with the help of advanced technology, the long-term strategy of many institutions, and the increasing unemployment rate during the tough time of the pandemic.

The paper provides many data to confirm that using the online format in education is a great option to choose because it provides flexible time and better access to teaching and learning opportunities for teachers and students during the COVID-19 pandemic. This paper has also provided some drawbacks of online format that users have to deal with, such as lacking efficiency in response time and lacking interaction and communication between people in online class due to technologies' problems and skills. However, these effects of online teaching and learning in English can minimize by designing the course work for a more efficient and desirable learning process.

\section{References}

Adams, N. B. (2007). Toward a model for knowledge development in virtual environments: Strategies for student ownership, International Journal for Social Sciences, 2(2),71-77.

Alien, I. E., \& Seaman, J. (2008). Staying the course: Online education in the United States. 
Needham, MA: Sloan Consortium.

Baik, M. J. (1992). Language Shift and Identity in Korea. Journal of Asian Pacific Communication, 3(1), 15-31.

Bates, A. W. (2005). Technology, e-learning and distance education (2nd ed.). New York: RoutledgeFalmer.

Biggs JB (1999). Teaching for Quality Learning at University Society for Research into Higher Education \& Open University Press, Buckingham

Bober, M. J., \& Dennen, V. P. (2001). Intersubjectivity: Facilitating knowledge construction in online environments. Educational Media International, 55(4), 241-50.

Byram, M. (2008). From Foreign Language Education to Education for Intercultural Citizenship Clevedon: Multilingual Matters.

Card, K. A. \& Horton, L. (2000). Providing access to graduate education using computermediated communication. International Journal of Instructional Media, 27(3), 235-245.

Cimer, S. O., Cakir, I., \& Cimer, A. (2010). Teachers' views on the effectiveness of in-service courses on the new curriculum in Turkey. European Journal of Teacher Education, 33(1), $31-41$.

Csikszentmihalyi, M. (1975). Beyond boredom and anxiety (1st ed.), Jossey-Bass, San Francisco, CA

Dan Tri News (2016). Only few students chose Chinese and Japanese in their National General Examination. Retrieved from http://tuyensinh.dantri.com.vn/tuyen-sinh/chi-vai-thi-sinhthi-tieng-trung-tiengnhat-20160701213613919.htm

Dong C., Cao S., Li H. (2020). Young children's online learning during COVID-19 pandemic: Chinese parents' beliefs and attitudes.Children and Youth Services Review, 118, Article 105440

Egbert, J. (2003). A study of flow theory in the foreign language classroom. The Modern Language Journal, 87, pp. 500-518

Egbert, J., \& Thomas, M. (2001). The new frontier: A case study in applying instructional design for distance teacher education. Language Learning \& Technology, 9(3), 391-405.

Egbert, Joy. (2003). A Study of Flow Theory in the Foreign Language Classroom. The Modern language journal (Boulder, Colo.) 87(4), 499-518.

Ellis, R. A. \& Calvo, R. A. (2004). Learning through discussions in blended environments. Educational Media International, 41(3), 263-274.

England, L. (2012). Online Language Teacher Education: TESOL Perspectives. New York: Routledge.

Harnette, M., St. George, A., \& Dron, J. (2011). Examining motivation in online distance learning environments: Complex, multifaceted, and situation dependent. International Review of Research in Open and Distance Learning, 12(6), 20-38.

Hiltz, S. R. (1986). The "virtual classroom': Using computer-mediated communication for university teaching. Journal of Communication. 36(20), 95-104

Hiltz, S. R. (1988). Collaborative learning in a virtual classroom: Highlights of findings. Paper presented at the Computer Supported Cooperative Work Conference, June 1988. (ERIC Document Reproduction Service No. ED 305 895)

Hiltz, S., Johnson, K. \& Turoff, M. (1986). Experiments in group decision making: 
communication process and outcome in face-to-face versus computerized conferences. Human Communication Research, 13(2), 225-252.

Hong, Hwang, Tai, and Lin (2017).Intrinsic motivation of Chinese learning in predicting online learning self-efficacy and flow experience relevant to students' learning progress. Computer Assisted Language Learning, 30, pp. 552-574

Johnson, D., Sutton, P. \& Poon, J. (2000). Face-to-face vs CMC: student communication in a technologically rich learning environment. Retrieved on 20 February, 2006

Lam,A., \& Chow, K. (2004). English language education in China: An update. In K.Tam \& T.Weiss (Eds.), English and globalization: Perspectives from Hong Kong and mainland China. Hong Kong: The Chinese University Press.

Li, Meng, Tian, Zhang, and Xiao, W. (2019). Modelling Chinese EFL learners' flow experiences in digital game-based vocabulary learning: The roles of learner and contextual factors. Computer Assisted Language Learning, 1, pp. 1-22

Liu, Honggang, and Xueyan Song (2021). Exploring 'Flow' in Young Chinese EFL Learners' Online English Learning Activities. System (Linköping) 96.

Maxwell, L. (1995). Graduate distance education: A review and synthesis of the research literature. Paper presented for the Annual Conference of the International Communication Association Instructional and Developmental Communications Division, Albuquerque, NM.. (ERIC Document Reproduction Service No. ED 387 118)

Moule, P. (2006). ?-learning for healthcare students: Developing the communities of practice framework. Journal of Advanced Nursing, 54(3), 370-380.

Nguyen, L. (2005, January). MOET strategies for teaching foreign languages at primary level. Paper presented at the Teaching English language at primary level, Hanoi, Vietnam.

Ramsden, P. (1991). A performance indicator of teaching quality in higher education: the course experience questionnaire. Studies in Higher Education, 16, 129-150.

Revere, Lee, and Jamison V Kovach (2011). Online Technologies for Engaged Learning: a Meaningful Synthesis for Educators. Quarterly review of distance education 12, no. 2, 113

Rumble, G., \& Latchem, C. (2004). Organizational models for open and distance learning. Policy for open and distance learning. In H. Perraton \& H. Lentell (Eds.), Policy for open and distance learning (pp. 117-140). London: Routledge Falmer.

Sabatini, J.P., Daniels, M., Ginsberg, L., Limeul, K., \& Russel, M. (2000). Teacher perspectives in the adult education profession: National survey findings about emerging profession. Philadenphia: National Center on Adult Literacy

Schieb, L. J., \& Karabenick, S. A. (2011). Teacher motivation and professional development: A guide to resources. Math and Science Partnership - Motivation assessment program. Ann Arbor, MI: University of Michigan

Tien Phong News (2016). National General Examination: Many foreign languages are chosen by only few students. Retrieved from http://www.tienphong.vn/giao-duc/ky-thi-thptquoc-gia-nhieu-mon-ngoai-nguchi-vai-thi-sinh-dang-ky-878024.tpo

Tiene, D. (2000). Online discussions: a survey of advantages and disadvantages compared to face-to-face discussions. Journal of Educational Multimedia and Hypermedia, 9(4), 371384. 
Trigwell, K and Prosser, M. (1996). Congruence between intention and strategy in science teachers' approach to teaching. Higher Education, 32, 77-87.

UNESCO. (2020). COVID-19 educational disruption and response.

Wang Q. Y. Woo H. L. (2007). Comparing asynchronous online discussions and face-to-face discussions in a classroom setting. British Journal of Educational Technology, 38(2), 272-286. 10.1111/j.1467-8535.2006.00621.x

Warschauer, M. (1995). Comparing face-to-face and electronic discussion in the second language classroom. CALICO Journal, 13(2), 7-26.

Wetzel, D. R. (2010). 12 expert twitter tips for the classroom: Social networking classroom activities that employ critical thinking. Retrieved from http://teachingtechnology.suitel01.com/article.cfm/12_expert_twitter_tips_for_the_ classroom 